\title{
POLA LALU LINTAS INFORMASI KOMUNITAS PENGUSAHA KAMPUS MEMBENTUK GERAKAN PENGUSAHA MUDA BEDA MENDUNIA MELALUI WHATSAPP MESSENGER
}

\author{
Santi Rahmawati, Irmulan Sati Tomohardjo, \\ Fakultas Ilmu Komunikasi Universitas Mercu Buana Jakarta \\ santirahmawati95@gmail.com, irmulan_sati@mercubuana.ac.id
}

\begin{abstract}
This research aim to know an information traffic pattern in community of Campus Enterpreneur which using Whatsapp messenger. This research method is case study and do in depth interview and observation. Aplied concepts in four pattern, base on Borderwijk and Van Kaam concept, these are allocution, conversation, consultation and registration. The result of information traffic pattern is in the beginning of recruitment, controlled information to the coordinating center of the Chairman (alokusi stage). Once incorporated in social networks, the conversation takes place between one member and the other (the conversation phase), about the mission vision, goals, organizational structure, work program, and existence in the community. The Chairman's directive ensures that every regional activity can work (consultation phase). And the Chairman receives and controls information from the members of the region regarding the agenda to be held (registration stage).
\end{abstract}

Keywords: Information traffic, community of campus enterpreneur

\begin{abstract}
ABSTRAK
Penelitian ini bertujuan mengetahui pola lalu lintas informasi Komunitas Pengusaha Kampus melalui Whatsapp messenger. Metode penelitiannya studi kasus, teknik pengumpulan data wawancara mendalam dan observasi. Konsep penelitian merujuk pada tahap alokusi (allocution), percakapan (conversation), konsultasi (consultation), dan registrasi (registration) dari Bordewijk dan Van Kaam. Hasil penelitian menunjukkan pola lalu lintas informasi pada awal perekrutan, informasi terkendali ke pusat koordinasi yaitu Ketua Umum (tahap alokasi). Setelah tergabung dalam jejaring sosial, percakapan terjadi antar satu anggota dengan anggota lainnya (tahap percakapan), tentang visi misi, tujuan, struktur organisasi, program kerja, dan eksistensi di lingkungan masyarakat. Arahan Ketua Umum memastikan kegiatan setiap regional dapat berjalan (tahap konsultasi). Ketua Umum menerima dan mengendalikan informasi dari para anggota wilayah terkait agenda yang akan diselenggarakan (tahap registrasi).
\end{abstract}

Kata-kata Kunci: Lalu lintas informasi, komunitas pengusaha kampus 
PENDAHULUAN

Dewasa ini, banyak sekali komunitas yang terbentuk dari adanya kemudahan yang diberikan oleh internet dan mereka biasanya mengumpulkan anggota komunitas dalam suatu grup online melalui media sosial atau pesan instan. Peluang tersebut yang kemudian dijadikan kesempatan untuk membentuk komunitas bisnis yang bernama komunitas Pengusaha Kampus (PK), khususnya di beberapa wilayah yang tersebar di Indonesia. Komunitas ini bertujuan untuk melahirkan pengusahapengusaha muda yang sukses dan keluar dari inisiasi kampus. Dengan adanya komunitas tersebut, maka diharapkan para pemuda Indonesia khususnya mahasiswa/i bisa memiliki bisnis dan membuka lapangan pekerjaan bagi masyarakat lainnya. Hal tersebut dapat membantu perekonomian Indonesia dan menurunkan persentase tingkat pengangguran.

Komunitas yang terbentuk sejak 23 Mei 2014, sudah memiliki anggota kurang lebih sebanyak 5.000 orang yang tergabung dalam grup chat Whatsapp messenger. Komunitas Pengusaha Kampus adalah rumah bagi komunitaskomunitas bisnis yang ada di kampus dan dikembangkan melalui jejaring sosial, dengan praktiknya program kerja bersifat nyata.

Komunitas Pengusaha Kampus sudah terbentuk di beberapa regional seperti PK Jakarta, PK Depok, PK Tangerang (Tangerang Kabupaten dan Kota, serta Tangerang Selatan), PK Bekasi, PK Bogor, PK Bandung, PK Banten, PK Jogja, PK Solo, PK Surabaya, PK Malang, PK Pekanbaru, dan beberapa daerah lainnya. Tiap-tiap regional tersebut rutin mengadakan kopi darat (kopdar) secara tatap muka agar antar anggota saling kenal dan mendiskusikan perkembangan bisnis atau bahkan merencanakan agenda untuk jangka pendek, menengah, maupun jangka panjang.

Penelitian ini difokuskan pada Komunitas Pengusaha Kampus regional Tangerang Selatan. Komunitas ini aktif menyelenggarakan berbagai kegiatan sosial, olahraga, dan aktif memberikan pelatihan kepada para anggota komunitas. Selain kopi darat, gerakan rutin yang dilakukan menggunakan Whatsapp messenger adalah Ngobrol Bisnis atau biasa disingkat NgoBis. Tangerang Selatan (Tangsel) juga merupakan salah satu kota yang mempunyai potensi yang sangat luar biasa di bidang bisnis, terutama sektor yang berhubungan dengan properti, jasa, 
hingga perdagangan. (Sumber: www.tangselmedia.com, diakses pada tanggal 4 Januari 2017) Proses antara anggota komunitas yang menggunakan media dalam bertukar informasi, sangat menarik dikaji, khususnya pola komunikasi mereka saat berkirim informasi, saling berperan satu sama lain dan aktivitas komunikasi lainnya.

Tujuan penelitian untuk mengetahui bagaimana pola lalu lintas informasi (information traffic) pada komunitas Pengusaha Kampus di Tangerang Selatan, Provinsi Banten, Indonesia. Pola lalu lintas informasi (information traffic) yang terbentuk pada komunitas Pengusaha Kampus dalam membentuk gerakan pengusaha muda, beda, mendunia melalui whatsapp messenger mengacu pada empat dasar pola lalu lintas informasi (information traffic) Bordewijk dan Van Kaam yang mengidentifikasikan pola baru dalam lalu lintas informasi, yaitu alokusi (allocution), percakapan (conversation), konsultasi (consultation), dan registrasi (registration).

\section{KERANGKA PEMIKIRAN}

Kerangka pemikiran diawali dengan melakukan kajian awal atas penelitian terdahulu, pertama mengutip dari Jurnal Skripsi berjudul Peran
Komunitas Wirausaha Muda Surakarta (WMS) sebagai Wahana Komunikasi Bisnis, yang ditulis Endang Saputri DF (http://www.jurnalkommas.com, pada tanggal 2 April 2018), yang menjelaskan tentang bagaimana peran komunitas Wirausaha Muda Surakarta sebagai wahana komunikasi binis. Penelitian tersebut menunjukkan bahwa komunitas Wirausaha Muda Surakarta melakukan komunikasi bisnis dalam marketing bisnis, mereka saling mendukung dan saling memberikan solusi bagi persaingan bisnisnya. Serta melakukan aktivitas rutin yang berupa "jagongan bareng" sekaligus mengoptimalkan blog, group facebook untuk membuka banyak relasi serta website untuk mendukung terciptanya kepercayaan masyarakat. Dengan menggunakan metode penelitian kualitatif deskriptif, teknik pengumpulan data wawancara, observasi dan dokumentasi. Serta menggunakan teori utama dari teori motivasi Mc Clelland yang menyatakan bahwa komunitas Wirausahs Muda Surakarta merupakan komunitas bisnis yang ingin mengubah persepsi masyarakat Surakarta untuk menjadi generasi yang lebih mandiri. Hal tersebut dipandang sebagai kebutuhan untuk memiliki efek positif pada organisasi dan untuk mendukung organisasi dalam mencapai tujuan itu. 
Selanjutnya mengutip pendapat McQuail (McQuail, 2008:159-160) menjelaskan pola baru dalam aliran informasi telah dikembangkan oleh dua ahli telekomunikasi Belanda, yaitu J.L Bordewijk dan B. Van Kaam. Mereka mendeskripsikan empat pola komunikasi dasar dan menunjukkan bagaimana polapola tersebut saling berelasi.

Pola lalu lintas informasi tersebut berada dalam konteks komunikasi organisasi. Disisi lain Goldhaber menjelaskan komunikasi organisasi sebagai proses menciptakan dan saling menukar pesan dalam satu jaringan hubungan yang saling tergantung satu sama lain untuk mengatasi lingkungan yang tidak pasti atau yang selalu berubahubah. (Khomsahrial Romi, 2011:13)

Definisi tersebut mengandung tujuh konsep kunci yaitu, pertama proses. Suatu organisasi adalah suatu sistem terbuka yang dinamis yang menciptakan dan saling menukar pesan di antara anggotanya. Maka gejala menciptakan dan menukar informasi ini berjalan terusmenerus dan tidak ada henti-hentinya, sehingga dikatakan sebagai suatu proses.

Kedua, pesan. Pesan adalah susunan simbol yang penuh arti tentang orang, objek, kejadian yang dihasilkan oleh interaksi dengan orang. Untuk berkomunikasi seseorang harus sanggup menyusun suatu gambaran mental, memberi gambaran itu, nama dan mengembangkan suatu perasaan terhadapnya. Komunikasi tersebut efektif kalau pesan yang dikirimkan itu diartikan sama dengan apa yang dimaksudkan oleh si pengirim.

Ketiga, jaringan. Organisasi terdiri dari satu seri orang yang tiaptiapnya menduduki posisi atau peranan tertentu dalam organisasi. Ciptaan dan pertukaran pesan dari orang-orang ini sesamanya terjadi melewati suatu set jalan kecil yang dinamakan jaringan komunikasi. Suatu jaringan komunikasi ini mungkin mencakup hanya dua orang, beberapa orang, atau keseluruhan organisasi. Hakikat dan luas dari jaringan ini dipengaruhi oleh banyak faktor, antara lain, hubungan peranan, arah dan arus pesan, hakikat seri dari arus pesan, dan isi dari pesan.

Keempat, keadaan saling tergantung. Hal ini telah menjadi sifat dari suatu organisasi yang merupakan suatu sistem terbuka. Bila suatu bagian dari organisasi mengalami gangguan maka akan berpengaruh kepada bagian lainnya dan mungkin juga kepada seluruh sistem organisasi. Begitu juga halnya dengan jaringan komunikasi dalam suatu organisasi saling melengkapi. Implikasinya, bila pimpinan membuat 
suatu keputusan dia harus memperhitungkan implikasi keputusan itu terhadap organisasinya secara menyeluruh.

Kelima, hubungan, karena organisasi merupakan suatu sistem terbuka, sistem kehidupan sosial maka untuk berfungsinya bagian-bagian itu terletak pada tangan manusia. Dengan kata lain, jaringan melalui mana jalannya pesan dalam suatu organisasi dihubungkan oleh manusia. Oleh karena itu hubungan manusia dalam organisasi yang memfokuskan kepada tingkah laku komunikasi dari orang yang terlibat dalam suatu hubungan perlu dipelajari.

Keenam, lingkungan yakni semua totalitas secara fisik dan faktor sosial yang diperhitungkan dalam pembuatan keputusan mengenai individu dalam suatu sistem. Lingkungan ini dapat dibedakan menjadi lingkungan internal dan eksternal, yang termasuk lingkungan internal adalah personalia (karyawan), staff, golongan fungsional dari organisasi, dan komponen organisasi lainnya seperti tujuan, produk dan sebagainya. Sedangkan lingkungan eksternal dari organisasi adalah langganan, leveransir, saingan dari teknologi.

Ketujuh, ketidakpastian yakni perbedaan informasi yang tersedia dengan informasi yang diharapkan. Untuk menukar ketidakpastian ini, organisasi menciptakan dan menukar pesan di antara anggota, melakukan suatu penelitian, pengembangan organisasi, dan menghadapi tugas-tugas yang kompleks dengan integrasi yang tinggi. (Arni Muhammad, 2009: 67) .

Selanjutnya dalam konteks komunikasi organisasi, juga terdapat elemen organisasi yang meliputi pertama, struktur sosial. Struktur sosial adalah pola atau aspek aturan hubungan yang ada antara partisipan di dalam suatu organisasi.

Komponen yang kedua adalah struktur tingkah laku. Komponen ini berfokus kepada tingkah laku yang diharapkan dan bukan pada resep bertingkah laku. Tingkah laku yang diperlihatkan manusia dalam organisasi ini mempunyai karakteristik umum yang merupakan pola atau jaringan tingkah laku.

Kedua, partisipan. Partisipan adalah individu-individu yang memberikan kontribusi pada masing-masing organisasi sangat bervariasi. Sifat kepribadian dari seorang partisipan organisasi juga akan bervariasi dari satu organisasi kepada organisasi lainnya, tergantung kepada tipe dan peranannya dalam organisasi tersebut.

Ketiga, tujuan organisasi. Konsep tujuan organisasi adalah yang paling 
penting dan sangat kontroversial dalam mempelajari organisasi. Ahli analisis mengatakan bahwa tujuan sangat diperlukan dalam memahami organisasi. Kemudian ahli tingkah laku menjelaskan bahwa hanya individu-individu yang mempunyai tujuan, sedangkan organisasi tidak.

Bagi kebanyakan analis, tujuan merupakan suatu titik sentral petunjuk dalam menganalisis organisasi. Tujuan dibatasi sebagai suatu konsepsi akhir yang diingini, atau kondisi yang partisipan usahakan mempengaruhinya, melalui penampilan aktivitas, tugas-tugas mereka.

Keempat, teknologi. Tiap-tiap organisasi mempunyai teknologi dalam melakukan pekerjaannya. Beberapa organisasi memproses materi input atau masukan dan membangun perlengkapan perangkat keras (hardware). Organisasi lainnya memproses orang, hasil produksinya berisikan individu-individu yang berpengetahuan, terampil atau individu yang lebih sehat.

Kelima, lingkungan. Setiap organisasi berada pada keadaan fisik tertentu, teknologi kebudayaan dan lingkungan sosial, terhadap mana organisasi tersebut harus menyesuaikan diri. Tidak ada organisasi yang sanggup mencukupi kepentingan dirinya sendiri.
Semuanya bergantung pada lingkungan sistim yang lebih besar untuk dapat terus hidup. (Arni Muhammad, 2009: 25).

Pada dasarnya dalam organisasi terdapat kelompok kelompok. Kelompok merupakan bagian dari kehidupan manusia. Tiap hari manusia akan terlibat dalam aktivitas kelompok. Demikian pula kelompok merupakan bagian dari organisasi. Dalam organisasi akan banyak dijumpai kelompok-kelompok ini. Hampir pada umumnya manusia yang menjadi anggota dari suatu organisasi besar atau kecil adalah sangat kuat kecenderungannya untuk mencari keakraban dalam kelompok-kelompok tertentu. Dimulai dari adanya kesamaan tugas pekerjaan yang dilakukan, kedekatan tempat kerja, seringnya berjumpa, dan barangkali adanya kesamaan kesenangan bersama, maka timbullah kedekatan satu sama lain. Mulailah mereka berkelompok dalam organisasi tertentu.

Kelompok diterjemahkan dari kata group diartikan seara harfiah sebagai kumpulan dua orang atau lebih yang mengadakan interaksi baik secara fisik atau juga psikologi dengan konstan. Atau juga sebagai suatu kesatuan yang dibentuk untuk mencapai tujuan bersama yang telah ditetapkan. Ada tiga elemen dalam sebuah kelompok yaitu :

1. Kegiatan 
Kegiatan terdiri dari tindakan-tindakan anggota kelompok yang berhubungan dengan tugas kelompok.

2. Interaksi

Dalam melakukan tugas tersebut mereka terlibat dalam suatu interaksi yaitu memperlihatkan saling ketergantungan dan saling menanggapi dalam bertingkah laku.

3. Perasaan

Interaksi akan melibatkan perasaan, yang terdiri dari perasaan negative dan positif yang dirasakan anggota kelompok terhadap anggota lain, seperti perasaan suka dan tidak suka. (Miftah Thoha, 2011: 79)

Individu anggota organisasi terse-

but, dalam melakukan komunikasinya bisa melalui tatap muka langsung ataupun bermedia, salah satunya media sosial. Kemunculan media baru seperti Whatsapp telah memberikan ruang terhadap pembentukan pola-pola baru dalam berkomunikasi. Selanjutnya McQuail menjelaskan pola baru dalam aliran informasi telah dikembangkan oleh dua ahli telekomunikasi Belanda, yaitu J.L Bordewijk dan B. Van Kaam. Mereka mendeskripsikan empat dasar pola lalu lintas informasi (information traffic) dan menunjukkan bagaimana pola-pola tersebut saling berelasi. Bordewijk dan Van Kaam (McQuail, 2008: 159) mengidentifikasi pola baru dalam lalu lintas informasi, yaitu alokusi (allocution), percakapan (conversation), konsultasi (consultation), dan registrasi (registration), berikut penjelasannya.

Pertama, alokusi (allocution) informasi disebarkan dari pusat secara bersamaan kepada banyak penerima dengan kesempatan umpan balik yang terbatas. Karakteristik lain adalah bahwa waktu dan tempat komunikasi ditentukan oleh pengirim atau di 'pusat'.

Kedua, percakapan (conversation), penggunaan pola percakapan, individu (dalam sebuah jaringan komunikasi potensial) berinteraksi secara langsung antara satu dan yang lain, melewati sebuah pusat atau perantara dan memilih rekan mereka sendiri, juga waktu, tempat, dan topik komunikasi. Pola ini berlaku pada beragam situasi di mana inter aktivitas dimungkinkan, termasuk pertukaran surat pribadi atau surat elektronik. Percakapan yang dimediasi secara elektronis, bagaimanapun biasanya membutuhkan sebuah pusat atau penengah (misalnya telepon atau penyedia layanan), bahkan jika tidak ada peranan aktif atau pemula dalam peristiwa komunikasi.

Ketiga, konsultasi (consultation), mengacu pada serangkaian situasi komunikasi individu (pada periperi) mencari informasi di pusat penyimpanan informasi, baik data, perpustakaan, karya rujukan, cakram komputer, dan 
sebagainya. Kemungkinan semacam itu volumenya semakin meningkat dan jenisnya semakin beragam. Pada prinsipnya, pola ini juga diterapkan pada penggunaan surat kabar tradisional yang berbasis konsultasi dan topiknya ditentukan oleh penerima di periperi dan bukan oleh pusat.

Keempat, registrasi (registration) adalah pola konsultasi yang berkebalikan, di mana pusat meminta dan menerima informasi dari partisipan di periperi. Hal ini berlaku kapan pun pencatatan pusat disimpan oleh individu dalam sebuah sistem dan pada semua sistem pertukaran panggilan telepon, dengan sistem alarm elektronik, dan dengan registrasi otomatis penggunaan perangkat televisi dalam penelitian khalayak 'people-meter' atau dengan tujuan-tujuan membebankan biaya kepada konsumen. Secara khas dalam pola ini, pusat memiliki kendali yang lebih atas individu di periperi untuk menentukan konten terjadinya lalu lintas komunikasi.

\section{METODOLOGI PENELITIAN}

Peneliti menggunakan paradigma post-positivistik sebagai cara untuk memandang permasalahan atau fenomena yang terjadi dalam suatu komunitas saat melakukan komunikasi yang membentuk suatu pola lalu lintas informasi. Serta peneliti menggunakan pendekatan kualitatif, dengan metode penelitian studi kasus.

Metode studi kasus merupakan strategi yang cocok bagi peneliti yang memiliki sedikit peluang untuk mengkontrol peristiwa yang akan diselidiki dan bilamana fokus penelitiannya terletak pada fenomena kontemporer (masa kini), serta bila pokok pertanyaan berkenan dengan "how" atau "why". (Robert K. Yin, 2003: 1) Teknik pengambilan data, dilakukan secara observasi dan ditentukan key informan untuk wawancara, yakni dengan Bapak Tegar, Koordinator Pengusaha Kampus Tangsel dan Bapak Nur Ali Muchtar sebagai Kordinator Pusat Pengusaha Kampus, mewakili pengurus komunitas Pengusaha Kampus.

\section{HASIL DAN PEMBAHASAN}

Pada dasarnya, komunitas Pengusaha Kampus terdiri dari sejumlah kelompok dan masing-masing kelompok terdiri atas sejumlah individu yang saling berkomunikasi antara satu sama lain untuk menukar pesan dalam satu jaringan hubungan. Sehingga saat melakukan proses komunikasi, komunitas Pengusaha Kampus melibatkan dua orang, beberapa orang, atau bahkan seluruh anggota, serta 
tidak menutup kemungkinan bekerja sama dengan pihak lain yang memiliki tujuan serupa.

Selain melakukan wawancara terhadap narasumber, peneliti juga melakukan observasi langsung dengan bergabung dalam grup chat Whatsapp komunitas Pengusaha Kampus Tangerang Selatan. Tujuannya yaitu untuk memperoleh informasi dan data terkait pola lalu lintas informasi (information traffic) yang terjadi pada komunitas Pengusaha Kampus Tangerang Selatan. Peneliti mengamati bagaimana pola lalu lintas informasi (information traffic) melalui percakapan yang terjadi antar koordinator dengan anggota dan anggota dengan anggota.

Hasil penelitian menunjukkan percakapan yang terjadi pada group chat Whatsapp komunitas Pengusaha Kampus sangatlah cair, tidak terlihat kaku, tidak ada batas waktu dalam menyampaikan informasi di grup. Sebanyak 211 orang anggota di grup chat Pengusaha Kampus, hanya sekitar 10 persen yang aktif memberikan tanggapan, itu berarti sekitar 20 orang saja yang aktif nge-chat group (istilah bagi anggota grup yang melakukan chatting di grup). Anggota yang aktif nge-chat group biasanya memberikan informasi yang berkaitan dengan kegiatan kewirausahaan, akan tetapi tidak jarang para anggota membahas hal-hal di luar tema kewirausahaan.

Kemudian untuk yang hanya sekedarnya saja memberi tanggapan, biasanya hanya sesekali muncul di grup untuk sharing atau menanyakan suatu hal. Selanjutnya, ada juga anggota yang hanya silent reader yaitu istilah bagi penghuni grup yang tidak pernah melakukan percakapan di grup dan hanya membaca informasi yang disampaikan dalam chat grup atau bahkan tidak dibaca sama sekali. Informasi yang disampaikan juga bermacam-macam, mulai dari yang serius hingga santai. Diantara ketua dengan anggota tidak seperti bos dan karyawannya, semua setara dan samasama berkontribusi dalam suatu agenda tanpa memandang siapa yang bisnisnya sudah maju atau baru saja memulai. Saling mendukung satu dengan yang lainnya, antara pengusaha yang sudah sukses dengan yang baru memulai juga saling memberikan dukungan dan motivasi. Bagi anggota yang sudah memiliki banyak pengalaman menjalankan bisnis, mereka saling berbagi ilmu kepada anggota yang baru belajar bisnis, begitupun sebaliknya.

Berikut ini, peneliti petakan gambaran bagaimana pola lalu lintas informasi komunitas Pengusaha Kampus. 


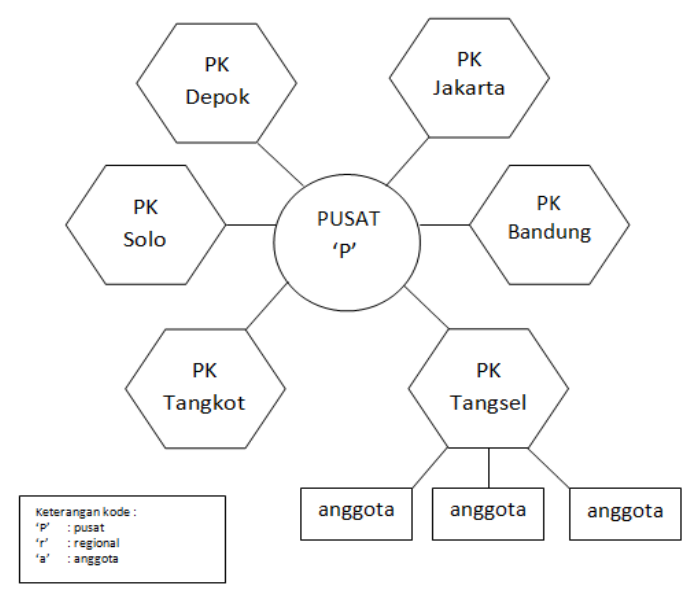

Gambar 1. Pola Lalu lintas Informasi Komunitas Pengusaha Kampus

Pada gambar tersebut, terlihat bahwa 'p' merupakan pusat yang terhubungan ke semua lini, yaitu komunitas Pengusaha Kampus regional atau ' $r$ '. Dimana, tiap-tiap ' $r$ ' memiliki struktur dan anggota pengurusnya masing-masing. Peneliti hanya memberikan gambaran pada regional Tangerang Selatan, sesuai dengan fokus wilayah yang peneliti telah pilih. Pola lalu lintas informasi (information traffic) yang terjadi dalam komunitas Pengusaha Kampus, ketika berkomunikasi menggunakan media Whatsapp sangat terlihat bahwa umpan balik yang diterima oleh pengirim pesan bisa didapat secara langsung.

Sebagai komunitas yang bergerak di bidang kewirausahaan, Pengusaha Kampus selalu berupaya agar program kerja yang telah dirancang memiliki dampak kepada masyarakat luas dan pastinya tingkat pengangguran di wilayah Indonesia semakin berkurang. Walaupun terbentuk secara massif melalui media online, akan tetapi program kerja yang dibuat bersifat nyata yang dinamakan gerakan pengusaha muda, beda, mendunia sesuai dengan tagline komunitas Pengusaha Kampus.

Berbagai kegiatan dilakukan dengan sasaran masyarakat sekitar terutama pemuda. Sampai saat ini, komunitas Pengusaha Kampus regional Tangerang Selatan selalu aktif mengadakan pelatihan kepada anggota yang sudah memiliki bisnis. Kedepannya komunitas yang terbentuk sejak tahun 2016, akan memfokuskan anggotanya yang sudah memiliki bisnis untuk bisa mengembangkan bisnisnya melalui kegiatan inkubator bisnis.

Saat ini, jumlah anggota PK Tangsel mencapai 217 orang, akan tetapi tidak semua anggota aktif dalam kegiatan 
yang diadakan oleh Pengusaha Kampus. Hanya sekitar 30 persen anggota yang aktif mengikuti setiap kegiatan Pengusaha Kampus. Bagi anggota yang tidak memiliki bisnis dan jarang mengikuti kegiatan yang diadakan oleh PK Tangsel, akan dianggap sebagai anggota non aktif.

Sesuai lima elemen organisasi yang saling berkaitan satu elemen dengan elemen lainnya, (Arni Muhammad, 2009: 25-28) diantaranya, pertama, struktur sosial, Komunitas Pengusaha Kampus memiliki struktur sosial, dimana dalam struktur tersebut saling berkaitan satu dengan yang lain. Walaupun struktur organisasi dan jobdesk sudah dibuat, akan tetapi terkadang para anggota belum menjalankan sesuai dengan perannya masing-masing. Salah satu divisi penting dalam suatu organisasi nirlaba adalah unit hubungan masyarakat (Humas).

Keberadaan humas dalam suatu organisasi menjadi sangatlah penting untuk menjembatani komunikasi dengan stakeholder internal maupun eksternal organisasi. Ketika suatu organisasi menjadikan humas sebagai ujung tombak, maka seorang humas harus memaksimalkan keberadaannya dalam organisasi untuk dapat menjadi perantara dalam arus informasi bagi organisasinya agar lalu lintas informasi (information traffic) antara organisasi dengan stakeholdernya dapat berjalan dengan baik. Peran seorang humas tidak hanya menangani hal-hal yang bersifat teknis tapi juga menyadarkan kepada lingkungan sekitar organisasi apa saja tujuan dari dibentuknya komunitas Pengusaha Kampus.

Oleh karena itu, walaupun komunitas Pengusaha Kampus adalah organisasi nirlaba dan bersifat informal, seorang humas organisasi harus memahami arus informasi pada organisasinya, sehingga kedepannya dapat melalui lalu lintas informasi dengan mudah dan terciptalah pola lalu lintas informasi (information traffic) yang sejalan dengan visi dan misi serta tujuan dari komunitas Pengusaha Kampus.

Kedua, partisipan. Bagi anggota PK Tangsel yang memiliki keahlian dibidang tertentu, biasanya mereka menjadi partisipan dalam beberapa kegiatan yang dilaksanakan oleh PK Tangsel. Seringkali individu tersebut mengerahkan dirinya untuk menjadi tutor atau pembicara dalam suatu acara atau seminar yang diadakan oleh PK Tangsel.

Ketiga, tujuan. PK Tangsel pun memiliki tujuan dalam melakukan setiap kegiatannya dalam bentuk visi dan misi yang diwujudkan bersama melalui 
gerakan pengusaha muda, beda, mendunia, merupakan tagline komunitas Pengusaha Kampus sekaligus tolok ukur kinerja komunitas. Program kerja yang dibuat tidak hanya berdasarkan kebutuhan dari para anggota komunitas, akan tetapi juga untuk mewujudkan harapan dan cita-cita seluruh anggota Pengusaha Kampus agar senantiasa bisa menjadi komunitas yang berdampak pada masyarakat lokal, nasional, maupun internasional. Uraian tentang muda diartikan sebagai keanggotaan PK yang selama ini terjalin adalah terdiri dari anak-anak muda rata-rata kurang dari 30 tahun, yang memiliki semangat berwirausaha dan menyebarkan pesan positif kepada masyarakat sekitar. Sebagai contoh yang menjalankan komunitas ini adalah para mahasiswa atau alumni yang sudah memiliki bisnis ataupun baru memulai untuk berbisnis.

Beda dapat diartikan sebagai salah satu upaya bagi anak muda zaman sekarang untuk memiliki pola pikir berbeda dari kebanyakan orang lainnya. Dalam artian bahwa, kebanyakan orang akan berpikir untuk melamar pekerjaan sebagai seorang karyawan atau staff di perusahaan setelah lulus dari perguruan tinggi. Namun, tidak dengan anggota Pengusaha Kampus yang berupaya agar sejak duduk di bangku kuliah sudah memiliki rencana akan berbisnis atau bahkan menjalankan bisnis. Sehingga, ketika sudah lulus bisa menuai apa yang sudah ditanam saat kuliah, yaitu hasil kerja keras dalam menjalankan bisnis. Seperti yang ditegaskan oleh Bapak Tegar bahwa:

"Kami itu mendunia... merupakan cita-cita yang ingin dicapai oleh Pengusaha Kampus agar bisa menjadi komunitas yang mendunia di masa depan. Bukan hanya untuk mengenalkan nama Pengusaha Kampus, akan tetapi juga untuk meningkatkan jumlah pengusaha di Indonesia yang kurang dari dua persen."

Gerakan pengusaha muda, beda, mendunia akan terwujud apabila setiap anggota menanamkan visi misi yang sama dengan Pengusaha Kampus. Seperti yang disampaikan Bapak Tegar berikut ini.

"Salah satu yang menjadi pertimbangan saya, selaku Ketua Umum Pengusaha Kampus regional Tangerang Selatan, yakni menambah program kerja seseuai dengan kondisi lapangan."

Selanjutnya Bapak Tegar juga menjelaskan tentang potensi keaktifan anggota serta apa yang diupayakan untuk mendukung program-program mereka, berikut petikan wawancaranya.

“Anggota PK Tangsel atau sekitar $70 \%$ anggota PK Tangsel, tidak aktif untuk ikut serta dalam kegiatan yang diadakan oleh PK Tangsel. Maka bersamasama yaa... pengurus PK Tangsel 
lainnya membuat program inkubator bisnis yang fungsinya untuk memberikan agenda coaching kepada anggota yang serius membangun bersama PK Tangsel. Kemudian, bagi individu yang tidak konsisten mengikuti kegiatan tersebut akan dianggap tidak aktif sebagai anggota PK Tangsel."

Keempat, teknologi. PK Tangsel juga sangat memanfaatkan teknologi yang ada untuk bisa mendapatkan kemudahan saat berkomunikasi. Sebagai asosiasi keanggotaan yang menghimpun para pengusaha yang berasal dari berbagai kampus, maka perlu adanya sumber daya manusia yang mendukung keberhasilan dalam memperjuangkan kebutuhan komunitas. Jantung dari keberhasilan asosiasi keanggotaan ini adalah hubungan dan hal ini menjadi fokus dari kegiatan public relations. Salah satu yang menjadi tugas seorang praktisi public relations dalam suatu komunitas adalah berupaya untuk mencari cara baru dan efektif untuk membangun serta memelihara sense of community. Hal tersebut tidaklah mudah, karena luasnya cakupan demografis keanggotaan dan tekanan waktu, jadwal, teknologi, serta kedekatan. Terlebih keanggotaan komunitas Pengusaha Kampus terdiri dari berbagai regional yang berada di pulau Jawa dan di luar pulau Jawa. Sehingga untuk menyelesaikan hal tersebut, peran public relations adalah dengan mengombinasikan penggunaan teknologi "lama" seperti newsletter, majalah, dan brosur, dengan teknologi "baru" seperti email, situs web, chat room, serta komunikasi tatap muka pada pertemuan regional dan nasional.

Kelima, lingkungan. Lingkungan merupakan hal yang sangat mendukung PK Tangsel dalam menjaga eksistensinya. Banyaknya jumlah organisasi nirlaba menciptakan lingkungan persaingan yang sangat ketat. Komunitas PK Tangsel bagaimanapun harus tetap menjaga eksistensinya apabila ingin tetap bertahan, serta berkontribusi untuk masyarakat sekitar agar tidak tergerus oleh kelompok sosial lain.

Kegiatan komunikasi biasanya lebih sering terjadi secara online melalui aplikasi whatsapp messenger, baik secara personal atau kelompok, sebagai media untuk berkomunikasi secara online, kemudahan yang ditawarkan, yang tidak ada pada aplikasi pesan instan lainnya. Menurut narasumber Bapak Ali sebagai koordinator pusat, bahwa:

"Saya betugas untuk memastikan bahwa program kerja yang telah dibuat oleh masing-masing wilayah dapat berjalan, saya juga memberikan arahan kepada koordinator wilayah dalam melakukan komunikasi."

Sedangkan, Bapak Tegar selaku koordinator wilayah PK Tangsel, menjelaskan bahwa: 
"Kalau saya berperan untuk mengajak anggotanya agar ikut berkontribusi sebagai panitia atau donatur dalam segala bentuk kegiatan yang diadakan oleh PK Tangsel."

Berdasarkan uraian konsep yang

telah dipaparkan sebelumnya, maka pola lalu lintas informasi (information traffic) yang terbentuk pada komunitas Pengusaha Kampus merujuk pada empat model pola baru lalu lintas informasi dua ahli telekomunikasi Belanda, Bordewijk dan Van Kaam (1986) sebagai berikut:

\section{a. Alokusi (Allocution)}

Pola alokusi terjadi ketika sebuah informasi mengalir dari satu sumber. Walaupun banyak khalayak yang menerima, tetapi informasi berasal dari satu sumber yang sama. Karakteristik lain adalah bahwa waktu dan tempat komunikasi ditentukan oleh pengirim atau di 'pusat'. Pada media baru, pola alokasi dapat terjadi pada fenomena line di jejaring sosial LINE@. Ketika official account seorang admin line@mem-posting tentang satu topik, misalnya bagaimana memulai bisnis saat kuliah, maka postingan tersebut akan terbaca oleh seluruh adders (sebutan followers bagi para pengguna line) yang sedang online. Namun, postingan tersebut tidak mendapatkan timbal balik secara langsung, arus informasi demikian masuk dalam pola alokasi. Pola lalu lintas informasi yang tidak menunjukkan adanya timbal balik. Pengusaha Kampus memiliki account official Line yang sering menyebarluaskan informasi kepada khalayak luas yang meng-add akun line Pengusaha Kampus dan berasal dari satu sumber yang sama. Namun, posting line tersebut tidak mendapatkan timbal balik, arus informasi. Akan tetapi, khalayak bisa membagikan informasi tersebut kepada khalayak lainnya. Dalam hal ini pusatlah yang memiliki kendali dalam penyebaran informasi. Awal perekrutan anggota juga dengan cara menyebarkan informasi dari pusat kepada khalayak yang tersebar, melalui kanal media yang dimiliki oleh komunitas Pengusaha Kampus.

\section{b. Pola Percakapan dan Pertukaran (Conversation)}

Pola percakapan terjadi ketika ada pertukaran informasi diantara dua orang atau lebih. Pola percakapan ideal menunjukkan adanya keseimbangan dimana pengirim dan penerima pesan berada pada satu kedudukan yang sama sehingga memungkinkan terjadinya interaksi. Setiap partisipan memiliki kekuatan yang seimbang untuk saling 
menyampaikan informasi. Pola percakapan terjadi ketika menggunakan telepon. Dalam media baru, interaksi yang menunjukkan pola percakapan dapat terjadi pada interaksi di chatroom, skype, videocall, ataupun forum diskusi online. Karakteristik dari pola percakapan ini adalah fakta bahwa semua pihak setara dalam pertukaran. Pada prinsipnya lebih daripada dua pihak dapat terlibat (misalnya pertemuan kecil, konferensi telepon, atau kelompok diskusi yang diperantarai komputer). Bagaimanapun pada titik tertentu, skala partisipasi yang meningkat berujung pada penyatuan dengan situasi alokatif.

Dalam hal ini, komunitas Pengusaha Kampus memanfaatkan media online seperti whatsapp, line, dan telegram untuk melakukan diskusi online. Interaksi yang dilakukan biasanya mengenai kegiatan yang sedang dan atau akan berlangsung, secara individu maupun kelompok, kemudian masingmasing dari mereka menceritakannya di grup. Semua pihak diperbolehkan untuk memberikan tanggapan atau informasi apapun, asalkan tidak mengandung unsur SARA dan menyinggung tentang politik.

\section{c. Pola Konsultasi (Consultation)}

Pola konsultasi terjadi ketika khalayak atau orang per orang ingin mencari informasi dari satu sumber yang sama, komunikasi hanya terjadi jika hanya ada permintaan dari khalayak. Misalnya saja internet dengan fasilitas alat pencariannya membuka peluang bagi banyak orang untuk mencari informasi melalui internet. Keadaan mengakses jurnal online, e-book sesuai kebutuhan juga merupakan bentuk pola konsultasi.

Terkadang untuk mendapatkan informasi yang bersifat sentral, koordinator komunitas Pengusaha Kampus wilayah mencari informasi ke pusat dengan melakukan interaksi personal menggunakan Whatsapp sebagai media.

\section{d. Pola Registrasi (Registration)}

Pola registrasi terjadi ketika pusat informasi menerima informasi dari berbagai khalayak lalu mengumpulkannya. Pola ini membuka peluang bagi khalayak untuk memberikan pada pusat lalu pusat bertugas mengumpulkan informasi. Hal ini terjadi pada media elektronik ketika melakukan telepolling. Pada media, pola registrasi terjadi ketika melakukan survey online. Pusat menjadi pengatur arus 
informasi yang masuk. Secara khas dalam pola ini, pusat memiliki kendali yang lebih atas individu di periperi untuk menentukan konten dan terjadinya lalu lintas komunikasi.

\section{Pada komunitas Pengusaha} Kampus yang terdiri dari beberapa regional ini saling memberikan informasi ke pusat terkait agenda yang akan diselenggarakan oleh salah satu regional untuk kemudian dari pusat membagikan informasi tersebut kepada regional lain mengenai informasi yang bersifat umum dan perlu untuk diketahui oleh khalayak luas.

Keempat pola tersebut saling berkorelasi membentuk suatu pola lalu lintas informasi, saling melengkapi dan membatasi satu sama lain. Pola alokasi di sini berlaku pada media 'lama' komunikasi massa pada umumnya. Sedangkan pola konsultasi telah dapat tumbuh karena adanya peningkatan jumlah saluran sebagai hasil dari kabel dan satelit. Media baru juga secara berbeda meningkatkan potensi 'komunikasi percakapan' atau komunikasi interaktif antara individuindividu yang terpisah jauh. Secara umum, hal itu mengimplikasikan pergeseran luas keseimbangan kekuatan komunikatif dari pengirim ke penerima, meskipun hal ini dapat diimbangi dengan pertumbuhan registrasi dan perkembangan lebih jauh jangkauan dan daya tarik media massa.

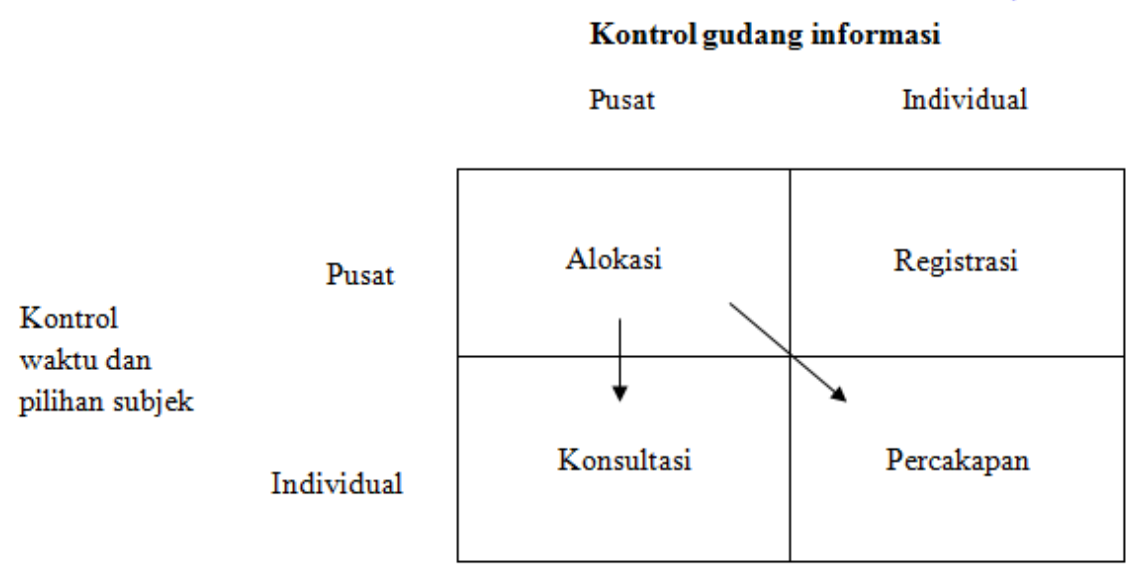

Gambar 2. Tipologi lalu lintas informasi (information traffic)

Anak panah yang tertera pada Gambar 2. Tipologi Lalu Lintas Informasi, mencerminkan penyebaran ulang lalu lintas informasi dari pola alokasi ke percakapan dan konsultasi. Pola alokasi belum betul-betul berkurang volumenya, tetapi telah mengambil bentuk-bentuk baru dengan penyediaan 
skala kecil untuk khalayak yang tersegmentasi berdasarkan kepentingan atau keperluan informasi.

Pada dasarnya pola lalu lintas informasi (information traffic) pada komunitas Pengusaha Kampus Tangerang Selatan dalam aksinya membentuk gerakan pengusaha muda, beda, mendunia melalui media Whatsapp messenger melalui tahapan pola lalu lintas informasi, yaitu pada awal perekrutan pusat menyebarkan informasi terkait keberadaan komunitas Pengusaha Kampus (alokusi), kemudian setelah mereka tergabung dalam satu grup Whatsapp percakapan terjadi antar satu anggota dengan anggota lainnya (percakapan). Selanjutnya ketika telah terbentuk berdasarkan hasil diskusi secara online maupun tatap muka mereka membuat visi misi, tujuan, struktur organisasi, program kerja, dan lain sebagainya agar komunitas PK kedepannya dapat tetap eksis di lingkungan masyarakat. Karena banyaknya anggota yang tergabung dalam komunitas PK dan tersebar di berbagai wilayah, maka tiap-tiap wilayah membentuk struktur dan program kerja berdasarkan kebutuhan masing-masing dengan tetap beraptokan pada saran dan arahan dari Ketua Umum (koordinator pusat), untuk itu pusat sangat berperan untuk mengarahkan dan memastikan kegiatan setiap regional dapat berjalan. Untuk itu, anggota harus senantiasa aktif konsultasi dengan koordinator pusat dalam meminta saran dan perbaikan. Hal tersebut mengacu pada pola konsultasi. Terakhir, bagaimana selanjutnya pusat meminta dan menerima informasi dari para anggota wilayah terkait agenda yang akan diselenggarakan dan pusat memiliki kendali untuk menentukan konten dan terjadinya lalu lintas komunikasi (registrasi).

Pengusaha Kampus sebagai sebuah komunitas yang dibentuk oleh sekelompok orang telah menginformasikan keberadaannya melalui berbagai jejaring sosial. Ketika suatu komunitas sudah memberikan kesempatan bagi organisasi manapun untuk berhubungan baik, maka ini menjadi peluang bagi seorang praktisi public relations suatu organisasi dalam menjalin kerjasama atau community relations dengan komunitas. Terlebih, pengusaha kampus merupakan suatu komunitas yang bergerak dibidang bisnis dan sosial, tentu perlu adanya jalinan hubungan baik dengan suatu organisasi/perusahaan sekitar.

Setiap komunitas memiliki saham penting dalam kestabilan ekonomi dan kesejahteraan lembaganya. Setiap organisasi memiliki saham penting dalam kestabilan ekonomi dan kesejahteraan 
dari komunitas di mana organisasi berada. Oleh karena itu, suatu hal yang wajar apabila organisasi dan komunitas membangun suasana saling berkepentingan dalam keberhasilan serta efektivitas masing-masing operasi. Hubungan baik antara organisasi dengan komunitas dapat dilancarkan dengan program community relations. Walaupun memang tidak semua permasalahan organisasi dapat diselesaikan dengan pendekatan community relations, akan tetapi dalam merumuskan masalah bisa dimulai dari memfokuskan pada komunitas organisasi.

Komunitas adalah semua stakeholeder yang dilayani oleh organisasi. Community Relations pada dasarnya adalah kegiatan Public Relations, maka langkah-langkah dalam proses PR pun mewarnai langkah-langkah dalam Community Relations. PR disini lebih dimaknai sebagai kegiatan organisasi dan bukan proses komunikasi yang dilakukan organisasi dengan publiknya. Kalau pun ada sedikit perbedaan dalam pendekatan pelaksanaan kegiatan, lebih disebabkan karena sifat kegiatan yang diselenggarakan dalam community relations. Mengingat community relations berhadapan langsung dengan permasalahan sosial yang nyata yang dihadapi komunitas sekitar organisasi. Melalui kegiatan ini, organisasi bersama-sama dengan komunitas sekitarnya berusaha untuk mengidentifikasi, mencari solusi dan melaksanakan rencana tindakan atas permasalahan yang dihadapi. Maka peneliti menilai, dengan adanya kegiatan community relations di setiap perusahaan, masalah-masalah sosial yang terus dihadapi akan berangsur membaik sesuai yang diharapkan perusahaan tersebut, tentunya dengan kerjasama yang baik pula dengan masyarakat sekitarnya sehingga citra yang baik pun akan didapatkan perusahaan tersebut. Satu prinsip yang hendak dikembangkan melalui kegiatan ini adalah mengembangkan hubungan bertetangga yang baik.

Tujuan dari program community relations (Iriantara, 2013), secara umum adalah memberikan informasi kepada komunitas mengenai kebijaksanaan, kegiatan dan masalah organisasi atau perusahaan, memberikan penjelasan atau jawaban terhadap pertanyaan atau tanggapan negatif bagi masyarakat sekitar perusahaan, memberikan bantuan kepada lingkungan melalui organisasi atau perusahaan setempat, bekerjasama dengan sekolah dan perguruan tinggi dengan menyediakan bahan-bahan pendidikan serta sasaran dan fasilitasnya, mendukung program-program kesehatan, mendukung kegiatan olah raga, budaya dan kreasi. 
Selain itu mengkaji konsep dasar yang dikembangkan oleh Jan L. Bordewijk dan Ben Van Kamm menempatkan orientasi kontrol sangat tinggi, maka model two ways communication menjadi alternatif yang diperlukan. Apalagi dalam situasi penggunaan media jejaring sosial yang menuntut proses komunikasi dua arah. Kontrol komunikasi yang terpusat serta pola yang memfokuskan pada peran kontrol dan tanpa kontrol, pola antara individu dan individu, sentral dan individu, sentral dan sentral serta individu dan sentral, seperti terurai pada gambar 2 diatas.

Sekaligus mengikuti pengembangan teori-teori media, khususnya diseminasi satu arah yang dipergunakan dalam komunikasi internal suatu komunitas, yang sifatnya cair, tentu menjadi keunikan tersendiri. Bahkan dapat menjadi suatu penemuan yang dapat dikaji lebih dalam di masa mendatanag, yaitu diseminasi satu arah (allocution). Serta bagaimana aplikasi dan perbedaannya saat diterapkan dalam lembaga komunitas yang cair dan lembaga yang memiliki merit system. Serta pengkajian dalam interaksi di dunia jejaring social yang sangat tepat menggunakan model Bordewijk dan Van Kamm ini, maka dapat pula dikemas dalam konsep khusus yakni interaksi di media jejaring sosial dan pola kontrol komunikasinya.

\section{SIMPULAN}

Dari hasil penelitian ini, dapat disimpulkan bahwa, pola lalu lintas informasi (information traffic) yang terjadi pada komunitas Pengusaha Kampus regional Tangerang Selatan terjadi secara online maupun offline. Namun, untuk menghemat waktu, interaksi lebih sering dilakukan secara online.

Komunikasi yang dilakukan secara online difasilitasi oleh aplikasi pesan instan yaitu Whatsapp messenger untuk saling berkomunikasi atau berdiskusi. Berdasarkan keempat modal yang mengacu pada pola lalu lintas informasi Van kaam dan Bordewijk, maka peneliti dapat menyimpulkan bahwa pola lalu lintas informasi (information traffic) pada komunitas Pengusaha Kampus Tangerang Selatan dalam aksinya membentuk gerakan pengusaha muda, beda, mendunia melalui media Whatsapp messenger melalui tahapan pola lalu lintas informasi, yaitu pada awal perekrutan pusat menyebarkan informasi terkait keberada komunitas Pengusaha Kampus (alokusi), kemudian setelah mereka tergabung da- 
lam satu grup Whatsapp percakapan terjadi antar satu anggota dengan anggota lainnya (percakapan).

Selanjutnya ketika telah terbentuk berdasarkan hasil diskusi secara online maupun tatap muka mereka membuat visi misi, tujuan, struktur organisasi, program kerja, dan lain sebagainya agar komunitas PK kedepannya dapat tetap eksis di lingkungan masyarakat. Anggota harus senantiasa aktif konsultasi dengan koordinator pusat dalam meminta saran dan perbaikan. Hal tersebut mengacu pada pola konsultasi.

Terakhir, bagaimana selanjutnya pusat meminta dan menerima informasi dari para anggota wilayah terkait agenda yang akan diselenggarakan dan pusat memiliki kendali untuk menentukan konten dan terjadinya lalu lintas komunikasi (registrasi).

Selanjutnya saran yang dapat peneliti usulkan, meliputi: a) Penelitian ini diharapkan bisa digunakan sebagai referensi bagi penelitian selanjutnya khususnya penelitian tentang lalu lintas informasi pada suatu komunitas bisnis. Dengan menggunakan pendekatan penelitian yang berbeda, pendekatan kuantitatif. Serta melakukan penelitian dengan metode survey eksplanatif dengan variabel penelitian berupa pengaruh media sosial terhadap efektifitas program para wirausaha muda, serta bagaimana jaringan komunikasinya berkembang dengan mengoptimalkan media jejaring baru yang saat ini sedang berkembang pesat. b) Pemahaman mengenai lalu lintas informasi suatu komunitas tidak hanya sebatas mengetahui bagaimana polanya saja, akan tetapi juga budaya yang terjadi dalam komunitas, karena saat ini banyak komunitas yang terhubung melalui media baru. c) Para anggota komunitas Pengusaha Kampus, di masa depan, dapat melakukan ekspansi dengan menambah jaringan di banyak perguruan tinggi dan membentuk pengurus cabang. d) Meningkatkan peran setiap anggota yang memiliki jobdesknya masing-masing agar senantiasa tidak hanya bergabung dalam keanggotaan, akan tetapi juga ikut memberikan kontribusi pada setiap kegiatan.

\section{UCAPAN TERIMAKASIH}

Ucapan terimakasih, tim peneliti sampaikan secara khusus kepada Ketua Umum dan Pengurus Komunitas Komunitas Pengusaha Kampus Regional Tangerang Selatan, serta para anggota komunitas yang telah berkenan memberikan informasi untuk selesainya penelitian ini. Bapak Tegar, Koordinator Pengusaha Kampus Tangsel dan Bapak 
Nur Ali Muchtar sebagai Kordinator

Pusat Pengusaha Kampus, mewakili

pengurus komunitas Pengusaha Kampus.

\section{DAFTAR PUSTAKA}

Iriantara, Yosal. 2013. Community Rekations. Bandung: Simbiosa Rekatama Media.

McQuail, Denis. 2008. McQuail's Mass Communication Theory. Sage Publication: London.

Muhammad, Arni. 2009. Komunikasi Organisasi. Jakarta: Bumi Aksara.

Romli, Khomsahrial. 2011. Komunikasi Organisasi Lengkap. Jakarta: PT Grasindo.
Thoha, Miftah. 2011. Perilaku Organisasi: Konsep Dasar dan Aplikasinya. Jakarta: PT Raja Grafindo Persada.

Yin, Robert K. 2003. Studi Kasus Desain dan Metode. Terjemahan. Jakarta: PT Raja Grafindo Perkasa.

\section{SUMBER NON BUKU}

Endang Saputri Dyana Fajarwati, Sofiah. 2016. Jurnal Skripsi : Peran Komunitas Wirausaha Muda Surakarta (WMS) sebagai Wahana Komunikasi Bisnis. FISIP Universitas Sebelas Maret Surakarta. diakses dari http://www.jurnalkommas.com pada tanggal 2 April 2018.

www.tangselmedia.com 